\title{
Architectural patronage in early-Victorian Huddersfield: the Ramsdens, William Wallen and J. P. Pritchett
}

\author{
CHRISTOPHER WEBSTER
}

\section{Introduction}

AS THE WEST RIDING manufacturing towns prospered in the first half of the nineteenth century on the back of the rapidly developing textile industry, there was a corresponding growth in the provision of professional services necessary to support the manufacturers. Thus, in Bradford there were twelve firms of attorneys in 1822, but thirty-five by $1853 ;{ }^{1}$ Halifax, with three firms of accountants in 1822, had seventeen 31 years later ${ }^{2}$ and there were also substantial increases in the provision of banking, insurance and transport services. It is all clear evidence of a thriving economy in the 'clothing district' towns. A not inconsiderable part of the new-found wealth was devoted to building. And this was not just utilitarian construction, but architecture, implying ambition and vision on the part of the patron and a project that required the services of a professional architect, not just a superior builder. It was often through its public buildings that these expanding towns competed with one another for status and were to be judged by visitors. In Leeds, a lone architect's office in 1809 had increased to eighteen in $1851^{3}$ and in Bradford, the two firms in 1822 had grown to thirteen in $1853 .{ }^{4}$ It is thus surprising that Huddersfield, well populated by other professionals, had no resident architect before 1838 when William Wallen chose to move from London, bringing to the town the benefits of his metropolitan training, experience and knowledge of current fashions there. ${ }^{5}$

The absence of a resident architect is not an implication that, before 1838, Huddersfield lacked dignified buildings - far from it. Indeed there was already a range of stylish churches, chapels, public buildings and mansions, but all were designed by architects from outside the town including, among the churches, 
Holy Trinity church (1816-19), by Thomas Taylor of Leeds; Emmanuel, Lockwood (1828-9), by R. D. Chantrell, also of Leeds; St Paul's (1828-30), by John Oates of Halifax; and the rebuilding of the parish church of St Peter (1834-6) was supervised by J. P. Pritchett of York [see Illustration 28, p. 133]. Meanwhile, the Congregationalists built the Ramsden Street Chapel (1824) to a design of Pritchett's [see Illustration 33, p. 149] while the Roman Catholic St Patrick's (1832) was by John Child from Leeds. Among the public buildings, Oates was responsible for Lockwood Baths (1827) and the Infirmary (1829-31) while Pritchett designed Huddersfield College (1838-9) and would soon be responsible for the magnificent railway station (1846-50).

Did it matter where these architects had their offices? On one level, perhaps not and the absence of a group of resident architects did not stop Friedrich Engels, in 1845, from concluding that Huddersfield's 'modern architecture' helped make it 'the handsomest by far of the factory towns of Yorkshire and Lancashire' - high praise indeed from a well-travelled commentator. ${ }^{6}$ However, having a resident architect was one of the signifiers of a town's confidence and its aspirations, and at a time when there was much civic pride among these expanding manufacturing communities, image and status mattered.As these towns sought to present a refined image to sceptical visitors, elegant, fashionable buildings were of crucial importance; it was the means by which the stigma of 'industrial wealth' might be mitigated by claims to culture and sophistication. The erection of the Philosophical Hall in 1836-7 (here attributed to Pritchett ${ }^{7}$ ) - a fashionably elegant exterior and a succession of worthy, 'improving' events within - was a crucial marker of such ambitions. The early-nineteenth-century historian Dr T. D. Whitaker wrote that Leeds 'had through its public [buildings] emerged from barbarism to a very high degree of elegance'; ${ }^{8}$ no doubt Huddersfield had similar ambitions. ${ }^{9}$

William Wallen, then aged thirty-one, arrived in Huddersfield in 1838 and established what quickly became a thriving architectural practice, the town's first. Over the next sixteen years he enjoyed considerable success and contributed a number of important buildings to the town. However, the story that follows is more than just architectural history. An examination of architectural patronage reveals much about how the town saw itself and the image it wanted to present; about the establishment of professional services in the town, an essential concomitant to industrial enterprise; and the significance of religious allegiances. It also tells us a good deal about the role played in the town's development by the Ramsden Estate during Huddersfield's physical transformation from 'a miserable village" ${ }^{10}$ to the "spacious' and "elegant"11 town centre that still largely exists today. This chapter focuses on two architects, J.P. Pritchett (1789-1868) and William Wallen (1807-88). Together they reveal much about the town in this seminal period of Ramsden influence. 
Where does this assertion that the town had no resident architect before Wallen leave Joseph Kaye, a master builder in the town and a man apparently capable of producing a sound design when one was needed? Kaye began his career as a builder around 1800 and over the next sixty years, according to Edward Law, erected a substantial proportion of the town's buildings and at one time employed over 1,000 men. ${ }^{12}$ Among the many building for which he contracted were several of those listed above including the Infirmary and St Paul's. The late-Georgian period witnessed the publication of a range of books illustrating, in straight forward terms, the principles of contemporary Classical architecture aimed at ambitious builders and joiners seeking to reinvent themselves as architects, and Kaye was one of them. ${ }^{13}$ But everyone in Huddersfield knew him as the owner of a huge and successful building firm and they knew he was not a proper architect, despite styling himself as one in the Directory of $1834^{14}$ and in several later ones. So, what precisely, at a time when there were no formal qualifications to be achieved prior to opening an office, did being a proper architect imply? Crucially, it was an independence from the building trades, the one issue that bedevilled Kaye's ambitions. As early as 1788 , the eminent London architect John Soane had set out a vision for modern practice.

The business of the architect is to make the designs ... and direct the works ...; he is the intermediate agent between the employer, whose honour and interest he is to study, and the mechanic [builder], whose rights he is to defend. [He is to oversee the builders, correct their mistakes and check their bills.] If these are the duties of an architect, with what propriety can his situation and that of the builder, be united? ${ }^{15}$

Initially, it was a radical idea, but slowly, through the first half of the nineteenth century, it took hold and gradually the services of an architect both to design and manage a project were seen as indispensable. And employing a wellknown architect brought prestige to the client as well as a stylish building.

Among the 'proper' architects, Pritchett secured many important commissions in the town, despite his York address; perhaps worried that Wallen was encroaching on his territory, he opened an office in Huddersfield in 1843, overseen by his son, Charles Pigott Pritchett, but the York office was always the principal one. Pritchett senior's employment in Huddersfield tells us much about how architectural patronage might operate. During the 1830s and 1840s Earl Fitzwilliam of Wentworth Woodhouse, near Rotherham, exerted extensive influence on the Ramsdens' management of Huddersfield, initially as an informal advisor during the final years of Sir John Ramsden's long life and then, between 1839 and 1852, as a Trustee for Sir John William Ramsden. Pritchett was Fitzwilliam's estate architect for over fifty years, from 
around 1815 , and seems to have been well-regarded by the earl. ${ }^{16}$ It is known that Fitzwilliam insisted Pritchett be appointed to build the new railway station in the town in 1846, ${ }^{17}$ 'the most splendid [station] façade in England', according to John Betjeman [see Illustration 22, p. 59]. No doubt Ramsden/ Fitzwilliam support assisted him to gain other important jobs. One came in 1834 with the decision to rebuild Huddersfield's decaying parish church of St Peter where the Ramsdens were the patrons, and as the lay impropriator Sir John Ramsden was obliged to pay the full cost of the work on the new chancel. This he did grudgingly and, no doubt, to maintain oversight of costs, promoted Pritchett for the whole project, despite his having only limited experience of this sort of work. The new building opened in 1836 [see Illustration 28, p. 133]. And it was Isabella, widow of John Charles Ramsden, who appointed Pritchett to rebuild the old church at Brotherton, near Pontefract, as a memorial to her husband in 1842.

Also useful as Pritchett's career developed were his Nonconformist associations. Despite having a father who was an Anglican rector, Pritchett was a prominent Congregationalist and in a town like Huddersfield, where Nonconformity was strong, his religious allegiance was undoubtedly useful. His first known commission in Huddersfield was the Ramsden Street Congregational Chapel (1824). With clear Nonconformist links of his own and Fitzwilliam promoting his interests in other respects, Pritchett was destined to prosper in the town.

The other prominent architect working in late-Georgian Huddersfield was John Oates from Halifax who added the impressive Infirmary and several Anglican churches in and around the town, including St Stephen, Lindley (1828-9); All Saints, Paddock (1828-9); and St Paul, Huddersfield (1828-30). His premature death in 1831 left a vacancy for a committed Anglican and it was into this void that Wallen stepped. The town would have struggled to find any young architect better trained or connected to welcome as its first resident architect. What made him seek his fortune in Huddersfield? The answer lies in his 1830 marriage to Frances Gill (1804-95), daughter of Richard Gill, Esq. and his wife, Mary, from Notton, ${ }^{18}$ a village between Barnsley and Wakefield, and twelve miles from Huddersfield. No doubt it was one of her relatives who alerted him to the opportunities offered in this expanding town with no architect of its own, and perhaps arranged some useful introductions. Given the way Wallen quickly cornered the market in Church of England projects - churches, schools and vicarages - it seems unlikely he did not have an influential ally.

Huddersfield certainly provided a sound base for Wallen's career as well as useful commissions for Pritchett, but in one respect it was a highly unusual town in the context of architectural practice: the normal relationship between 


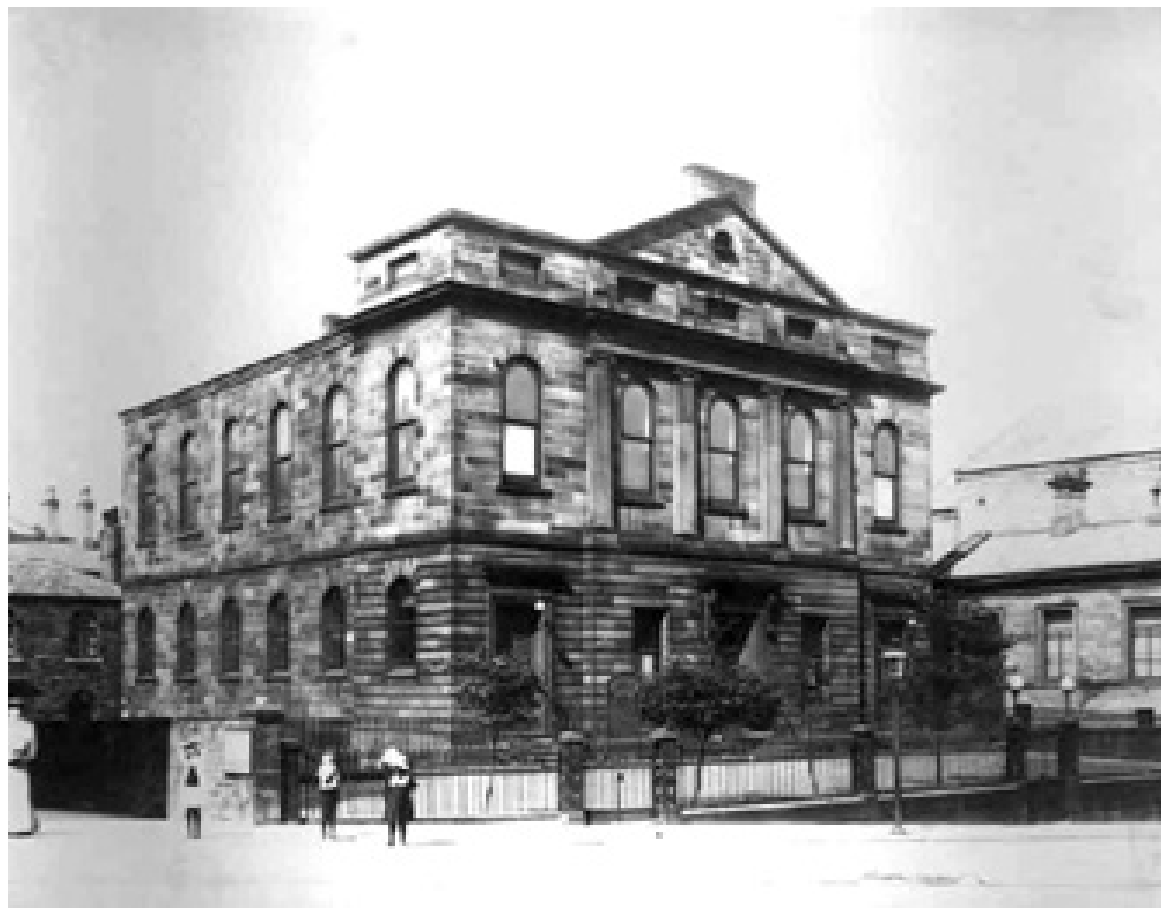

33. Ramsden Street Congregational Chapel (1824), by J. P. Pritchett, demolished 1936.

Kirklees Image Archive

client and architect was complicated by the involvement of the Ramsden Estate, intent on overseeing the town's physical changes. This was especially true from 1844 when the diligent George Loch was appointed estate steward; Loch, assisted by Alexander Hathorn, the local agent, carefully controlled both the overall development of the town and the individual new buildings within it. And Isabella Ramsden, a woman of 'strength and intuition', ${ }^{19}$ and uncompromising opinions on a range of topics, regularly expressed her thoughts on architectural matters. The trio certainly kept architects on their toes even when it was not Ramsden money paying for the buildings.

\section{Wallen's early life and training}

We know a great deal about Wallen's pre-Huddersfield life thanks to the eminent men to whom he was related or with whom he associated. Wallen was certainly better trained and connected, and more talented than most, but as an ambitious young architect seeking to establish an office in a developing provincial town, he was far from alone. 
Wallen was born in 1807, the son of the London architect John Wallen (1785-1865). The family lived in a series of elegant houses in Spitalfields, London, from where John ran his practice. John had been a pupil of Daniel Alexander, a brilliant and successful architect for whom Pritchett had once worked, who excelled at the design of large industrial buildings, warehouses, prisons and dockyards which often involved staggeringly large budgets and provided an essential component in Britain's world-wide industrial and mercantile supremacy. They were looked on with amazement by informed foreign visitors to the capital. John had several pupils who went on to enjoy notable careers and it seems that the training he offered was of an exceptional standard. ${ }^{20}$ William Wallen thus enjoyed an unusually thorough architectural education in his father's office. The formal part of his pupillage is likely to have been completed around 1828 , by which time he would have been 21 . There is then a ten-year gap before he began independent practice in Huddersfield. His activities in this decade, and the men with whom he was associated, give a clear picture of his energy and ambitions, and reveal a young architect of outstanding ability. He became a partner in his father's firm in $1831 .{ }^{21}$

\section{Wallen's antiquarian interests}

Wallen was also acquainted with many of the leading antiquaries of the period, especially through the Topographical Society of which he was secretary in the 1830s. ${ }^{22}$ His antiquarian interests had already been brought to the public's attention when, between 1828 and 1833, he exhibited a total of eight works of art at the Royal Academy, mainly depictions of medieval buildings. ${ }^{23}$ In 1835, he was elected a Fellow of the Society of Antiquaries, ${ }^{24}$ an impressive attainment for a twenty-eight year old. The following year he published The History and Antiquities of the Round Church at Little Maplestead, Essex. ${ }^{25}$ It is an important piece of research from a writer who had adopted the very highest standards of contemporary scholarship and it received a positive review in the Architectural Magazine; ${ }^{26}$ it was illustrated by eight accomplished plates by Wallen. There were 510 subscribers of which 106 were architects, including most of the eminent, London-based practitioners. Twelve subscribers came from Huddersfield and its immediate surroundings, including a 'Mrs Gill' and a 'Miss S. Gill' of Huddersfield, presumably his in-laws. That Wallen had these contacts is a likely explanation for his hitherto unlikely arrival in the town two years after publication.

On 30 January 1838, at the very beginning of his independent career, Wallen delivered a paper at the Architectural Society's meeting in London. It was titled 'On Prejudice as to Style in Architecture'. Conveniently, it was printed. ${ }^{27}$ In the lecture, he cautioned against adherence to a single style: 'this 
unhappy perversion has swayed alike the mere tyro and the consummate master'. Instead he urged a more catholic approach: no styles 'are deserving of utter condemnation.' He proceeded to deliver a brief history of architecture from the Greeks onwards, taking a swipe along the way at the 'ignorant' use of Gothic by Inigo Jones and Christopher Wren. He urged a careful study of whatever style a patron requested, a philosophy soon to be borne out by his own career in Huddersfield.

\section{Wallen in Huddersfield}

Nationally, the first half of the nineteenth century contains many examples of London trained architects identifying an opportunity in an expanding provincial town and relocating in order to exploit it. Thus, both Thomas Taylor and R. D. Chantrell moved to Leeds and Richard Pope went to Bristol, while G. T. Andrews settled in York. Usually, these practices developed relatively slowly. However, in Wallen's case he seems to have established himself with remarkable rapidity. His known early commissions were almost all concerned with Church of England projects - churches, schools and vicarages suggesting the town was on the look-out for not just a talented architect, but a talented one with solid Anglican credentials.

His earliest known job in the Huddersfield area was St David's church, Holmbridge, in the parish of Almondbury where the Ramsdens were lords of the manor. The project gives some idea of the complexity of church building in this period, especially where there was reliance on a grant from the Londonbased Incorporated Church Building Society, as many projects did. A church for this isolated community was deemed desirable and a grant was successfully applied for in $1832 .{ }^{28} \mathrm{~A}$ design was solicited from Henry Ward, then in Wakefield ${ }^{29}$ - although soon to move to Hanley, Staffordshire - but no suitable site could be found. When, in 1837, a site was found, tenders for the scheme exceeded Ward's estimate. He could not be contacted, or perhaps had lost interest in the project, and in June 1837 new designs were provided by Chantrell. Although an experienced church architect who had successfully undertaken a number of jobs part-financed by the ICBS, the Society's Surveyor objected to the closeness of the galleries. Chantrell made revisions approved by the Surveyor in July, but the Society withheld final approval for some unspecified reason. ${ }^{30}$ On 3 March 1838 Almondbury's vicar, Lewis Jones, again asked the ICBS what was causing the delay as he was keen to start building. He went on to enquire whether the ICBS would return Ward's plans, claiming - rather disingenuously - they 'might suit another design for a church on a large scale in this neighbourhood' ${ }^{31}$ These plans were duly returned. 
Jones, having retrieved Ward's plans, already approved and for which a grant had been secured, then abandoned the Chantrell scheme and sought an architect to supervise the erection of Ward's design. On 18 March 1838 he asked Chantrell to oblige but the latter declined believing such a course to be 'unprofessional' and had already been told that some other person was 'going to execute Ward's plan'. ${ }^{32}$ This is confirmed by a letter from Wallen to the ICBS, dated 7 March 1838, only four days after Ward's plans were requested, stating 'the Building Committee had appointed me to carry into erection the church at Holmbridge, relinquishing all the plans previously to this date, and have determined upon erecting the original design of Mr Ward to which the [ICBS's] official seal has been attached ... the committee have appointed me to act as surveyor of the works and superintend the erection of the church .....$^{33}$ Clearly, early in 1838 Jones must have had discussions with Wallen and lined him up to take over the Holmbridge project. Other than the chancel, added by Edward Hughes in the 1880s, the design is largely as shown in Ward's c.1832 plan. The obvious difference is that a much more substantial tower was built. The foundation stone was laid on 28 May 1838 and the church was consecrated in July $1840 .{ }^{34}$

Wallen must have impressed as, soon after securing the Holmbridge job, he was asked to survey the medieval parish church of Almondbury. His report, of 29 June 1838, identified several problems with the roof - rotten timbers, collapsed trusses and missing slates - and concluded immediate

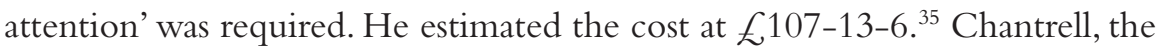
area's most eminent church architect, had undertaken work in the church in 1829-30 and might have anticipated securing this commission. However, the real crown for Wallen in the late-1830s was his victory in the competition for designs for the new Church of England Collegiate School in Huddersfield. The Leeds Intelligencer of 27 October 1838 announced his triumph in its 'Local Intelligence' section and the same edition carried an advertisement stating Wallen had moved from his London address - listed as Great Marlborough Street - to Buxton Road, Huddersfield, where he would welcome potential clients. However, he must already have been spending significant amounts of time in the town. Construction of the school began early in $1839 .{ }^{36}$

Perhaps nothing better illustrates the religious divisions in Huddersfield than late-1830s educational provision for the children of the town's middleclass elites. It also reveals something of the rivalry between Wallen and Pritchett, as well as the bases for their support. The area already had several long-established grammar schools - Almondbury, Longwood and Fartown which offered a traditional classical education, but by the 1830s 'there was felt to be a need for a secondary school ... where the sons of woollen magnates and wealthier trades people might be educated ... [with] a more modern 
curriculum than the grammar schools could provide. Furthermore, the Nonconformist elements in the town resented the interest of the established Church in the older schools. ${ }^{37}$ Thus in 1838, the Revd W. A. Hurndell of Ramsden Street Congregational Chapel was instrumental in founding the Huddersfield College Company, floated with 300 shares at $\mathcal{E}^{20}$ each. The college opened in temporary premises on 21 January 1839 and moved to its handsome new building on the fashionable New North Road in 1840, designed by Pritchett. It followed closely behind Wakefield's Proprietary School which opened in 1834, which was also independent of Anglican influence, was aimed at a similar clientele, and also offered a 'modern' curriculum including European languages and mathematics.

It is no coincidence that 1838 also saw the establishment of Huddersfield's Collegiate School, adopting the best name available after its rival had already settled on 'College'. It also proposed a modern curriculum, but one based 'upon the doctrines and practices of that Protestant Church of England to which the Headmaster belonged'. ${ }^{38}$ The Archbishop of York and Bishop of Ripon headed the list of its patrons, confirming its Anglican affiliations. It also opened in January 1839 in temporary premises, ${ }^{39}$ and moved into the building designed for it by Wallen in $1840 .{ }^{40}$ What better credentials could he have had for securing future Anglican patronage in the town? Indeed, through the 1840s, Wallen received a significant amount of it. In addition to the church at Holmbridge, he was responsible for four new churches in West Yorkshire: St John the Evangelist, Farsley, Leeds (1842-3); ${ }^{41}$ St Luke, Milnsbridge (1843-5); $;{ }^{42}$ Christ Church, Oakworth, near Keighley (1844-6); ${ }^{43}$ and St Paul, Shepley (1845-8) [see Illustration 36, p. 157]. ${ }^{44}$ There was also the chapel of ease at Aspley, 'attached' to St Paul's church (c.1853-4), sometimes referred to as the Aspley Lecture Room. ${ }^{45}$ His other work for the Anglicans included repairs in 1839 to St Stephen's, Lindley (designed by John Oates, $1829)^{46}$ and the redecoration of St Lucius, Farnley Tyas (designed by R.D. Chantrell, 1838-40) in 1843. ${ }^{47}$ After damage caused by the 'great Holmfirth flood' in February 1852, Wallen supervised the 'Restoration, Alteration and Additions' to Holmbridge church and the restoration of the churchyard wall and gate piers. ${ }^{48}$

Associated with the Anglican churches was a series of new schools, schoolmasters' houses and parsonages. He built Holy Trinity school, Portland Street, Huddersfield (1840), ${ }^{49}$ a school and parsonage to complement his church at Holmbridge (1841-2), ${ }^{50}$ a National School and schoolhouse at Almondbury (1844-5), ${ }^{51}$ a National School and master's house at Kirkheaton (c.1844-5), ${ }^{52}$ a school 'attached' to St Bartholomew's at Marsden (1846) ${ }^{53}$ and a parsonage for Milnsbridge (1846) ${ }^{54}$ To put these successes in context, Pritchett's Anglican employment in the Huddersfield area during the 1840s 


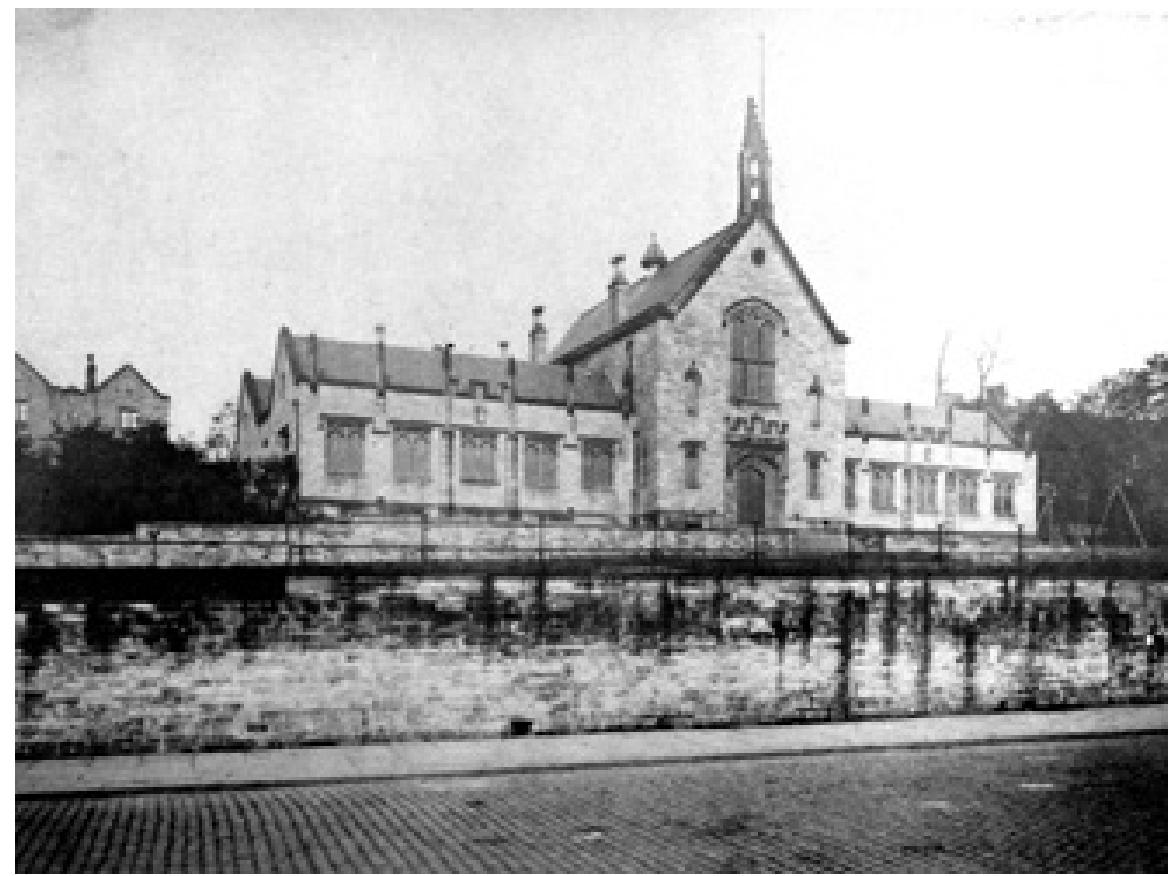

34. Huddersfield Collegiate School (1839-40), by William Wallen. Kirklees Image Archive

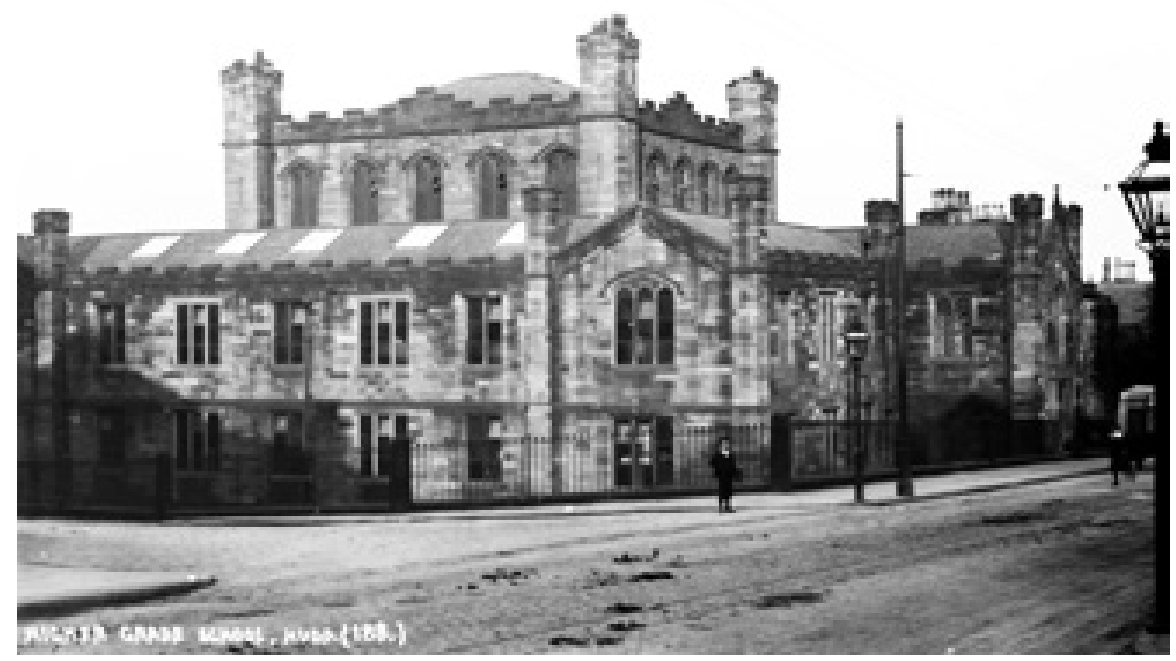

35. Huddersfield College (1839-40), by J. P. Pritchett.

Kirklees Image Archive 
was limited to the completion of the church, school and houses at Meltham Mills, a project started before Wallen's arrival in the town, and the new vicarage for Huddersfield parish church, erected near Greenhead in $1842 .{ }^{55}$

Despite all the newly-built churches, the 1840s was a turbulent time for Anglicans. The rapid advances of the Cambridge Camden Society - often referred to as the Ecclesiologists - formed in 1839 and intent on pushing the Church of England in a 'Higher' direction, caused serious turmoil among Anglican church-builders as well as worshippers. The society was intent on reviving decoration and liturgy banished by the Puritans, and encouraged the building of new churches that more faithfully followed pre-Reformation models; 'preaching box' layouts were soon deemed repellent by its supporters and 'Gothic authenticity' was the new imperative. Impressive support for the Cambridge Camden Society came quickly. After only four years of existence, it could boast the patronage of both archbishops and twelve other bishops. Low Church Evangelicals - and one of their strongholds was Huddersfield - must have felt decidedly marginalised. The society claimed the moral high ground and there was little room for those who merely wanted to maintain the status quo. ${ }^{56}$ Of central importance in spreading the Ecclesiological message to the provinces were the 'diocesan' societies that sprang up around the country from the early 1840s. The first was the Exeter Diocesan Architectural Society, founded in 1841, quickly followed by the Yorkshire Architectural Society, founded in 1842. The agendum of these groups was, ostensibly, the study and restoration of medieval churches in their areas, but there was certainly a more subversive one: to influence the design and layout of new churches to make them suitable for Ecclesiological liturgy.

\section{Yorkshire Architectural Society and some publications}

Wallen was a founder and, initially, very active member of the Yorkshire Architectural Society, the objective of which was

to promote the study of Ecclesiastical Architecture, Antiquities and Design, the restoration of mutilated architectural remains and of Churches or parts of Churches which may have been desecrated, within the County ofYork; and to improve, so far as may be within its province, the character of Ecclesiastical Edifices to be erected in future. ${ }^{57}$

Like the other societies, the Yorkshire group was dominated by the clergy, but at its first formal meeting after formation, it was agreed:'Those architects who really understand the principles of Gothic architecture and of ecclesiastical design, and only want room, and liberty, and a just appreciation of their talents to distinguish themselves will, we are persuaded, find in the Yorkshire 
Architectural Society a very effective ally.' Indeed, Wallen, as the first architect member, was present to hear these words, and over the next few years he would be joined by most of the leading Yorkshire architects who specialised in church work, including Chantrell. It was at this first meeting, on 29 September 1842, that Wallen was elected to the committee.

During its early years, he appears to have been a diligent supporter and a regular attender at committee meetings, despite these initially being held at a variety of locations round this very large county. He also sat on various sub-committees - for instance those overseeing the restoration of Howden Minster in 1842, and the Chantry Chapel, Wakefield the following year. At the first AGM in 1842, he presented the society with 'an illuminated copy' of Little Maplestead, possibly the first item acquired for the library. At the second AGM, held in York in October 1843, he read his paper on 'The Geometrical Principles of Gothic Architecture', and after the committee meeting in Halifax in November he repeated it. ${ }^{58} \mathrm{He}-$ and Chantrell - were re-elected to the committee at the October 1844 meeting, but neither attended any meetings during the year and they were not re-elected to the committee at the annual meeting of October 1845. Were they just too busy elsewhere to continue? Possibly, but having initially been such active members, one is left wondering if there had been some falling-out. ${ }^{59}$ Perhaps Wallen found it increasingly difficult to defend the modest, box-like churches his Low Anglican congregations desired. He remained an ordinary member until at least $1850 .{ }^{60}$

Wallen's Two Essays Elucidating the Geometrical Principles of Gothic Architecture, the basis for his YAS lectures mentioned above, were initially delivered to the Geological and Polytechnic Society of the West Riding of Yorkshire late in 1841 and were published in Leeds in $1842 .{ }^{61}$ They were, no doubt, a significant means of bringing him into the orbit of the YAS's clerical founders. Identifying the principles of proportions which had guided the architects of the great medieval cathedrals, abbeys and churches was a

subject that exercised many a Gothic scholar during the nineteenth century. ${ }^{62}$ Through his 'personal investigation of our ancient edifices' he developed a persuasive 'system' to explain the use of proportions in the Middle Ages. ${ }^{63}$ Although theories like Wallen's are now generally dismissed, exploration of these themes in the 1840s placed him within an elite group of London-based researchers and must have brought him significant prestige.

\section{Wallen's churches}

Given Wallen's work with the YAS and his publications, it would be hard to imagine an architect setting out on a church-building career around 1840 who could boast better qualifications for the task or who had more impressive 


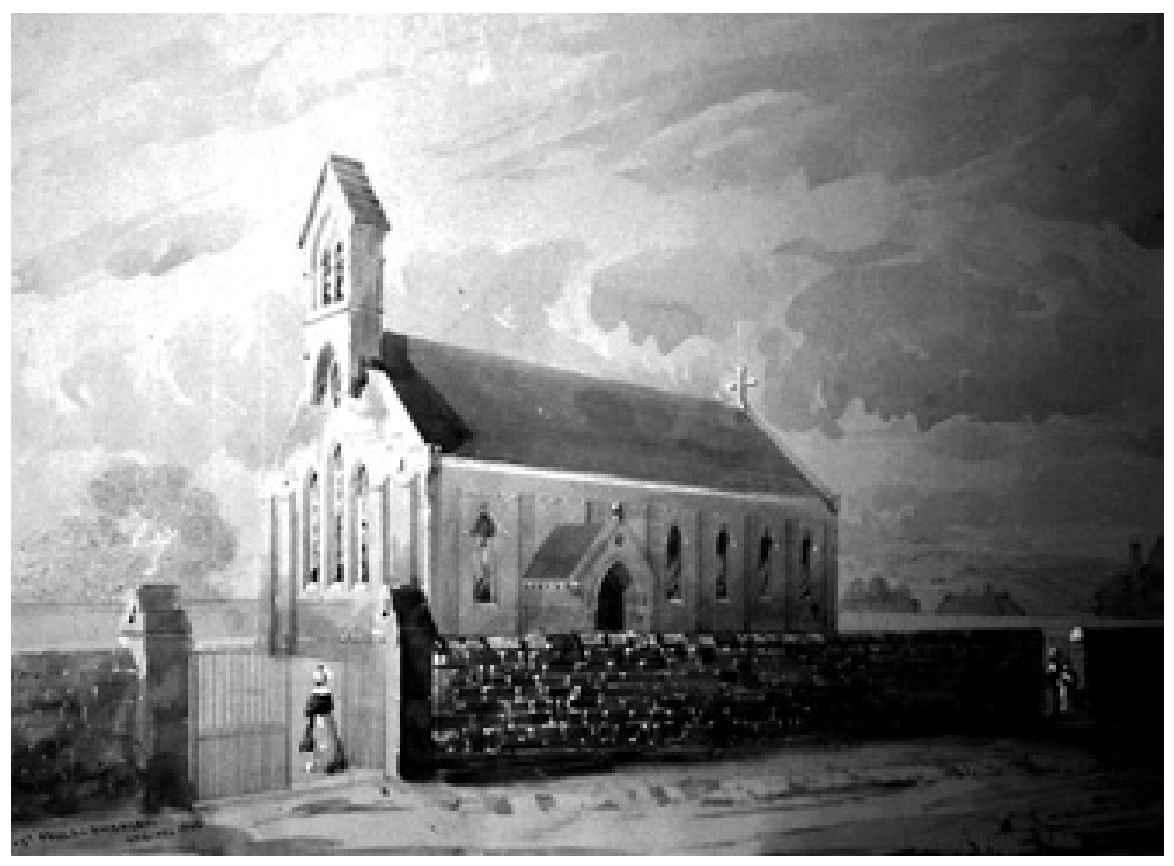

36. St Paul, Shepley (1845-8), by William Wallen.

Leeds University, Special Collections MS 78.

external interests. He might have been expected to be a torch-bearer for the Ecclesiologists, yet his churches suggest quite the opposite. Specifically, while the Ecclesiologists urged architects to specify long chancels, steeply pitched roofs and clerestoried naves, and never to incorporate galleries, in many respects Wallen's designs of the 1840 s remained firmly wedded to pre1840 ideals: box-like naves undivided by arcades, shallow roofs and always a gallery, sometimes on three sides of the nave, as at Milnsbridge. And several of his churches - for instance Whitehaven and Shepley - have no chancel at all while others are modest in length. ${ }^{64}$ Clearly Wallen was not an enthusiastic Ecclesiologist. His apparent reluctance to fully embrace the group's thinking is surely bound up with patronage: the Huddersfield area was a stronghold of Low, Evangelical Anglicanism where a revival of High Church practices was initially mistrusted and treated with deep suspicion. ${ }^{65}$ Crucial in Evangelical worship was the congregation's ability to hear and see, and nothing hindered the transmission of sight and sound more than arcades of columns, while galleries brought the maximum number of worshippers close to the pulpit.

Many historians of the early Victorian period have become somewhat blinkered by the pervasive propaganda of the Ecclesiologists to the extent 
that what was deemed a failure in their eyes continues to be marginalized. But if we can accept that Wallen and his clients had little interest in faithfully reproducing medieval churches, we are liberated from the highly subjective confines of Ecclesiological 'success'. As we have seen, Wallen certainly had an academic interest in the architecture of the Middle Ages ${ }^{66}$ but, it seems, his approach to the design of modern churches was much more pragmatic, especially when budgets were small as was invariably the case with his commissions. A particularly revealing passage from his Essays is this: he condemns those who believe "every pointed building must be a cathedral or nothing; nor shall we attempt to copy some vast church within a twentieth part of the space, and with a hundredth part of the money. ${ }^{97}$ Evidence that Wallen took a consciously anti-Ecclesiological stance - or, indeed, any stance - is frustratingly elusive, although there are one or two hints in that direction. Crucially, his Essays include his opinion that in all but the largest churches, 'the width does not justify the inclusion of aisles': they spoil the proportions and mask the pulpit from parts of the congregation. ${ }^{68}$ In the heady days of the Ecclesiological revolution, this was a refreshingly independent and rational idea. And the inclusion of west galleries in all his churches in order to produce a satisfactory level of accommodation was equally reactionary. ${ }^{69}$

Wallen has left few comments about style, although his Essays include his belief that 'late-Gothic' was 'gorgeous'. ${ }^{70}$ However, rather than adopt this, or Decorated - the Ecclesiologists' favourite - his churches are either Norman or Early English, a stylistic selection probably informed by the limited budgets. Yet even with modest funds, these churches are not dull or bare. Indeed, the combination of a Norman chancel arch with over-sized decoration, supported by debased Corinthian half-columns at Milnsbridge or the incorporation of the vesica piscis as a decorative motif at Holmbridge and Oakworth, suggest Wallen had little interest in archaeological fidelity but was, perhaps, a pioneer in the drive to develop Gothic as a modern idiom, a concept subsequently promoted eloquently by Beresford Hope and his circle. ${ }^{71}$

How well were Wallen's churches received? The simple answer seems to be, enthusiastically. At their openings, Holmbridge was described as 'pretty and commodious' ${ }^{72}$ and Milnsbridge as 'elegant'. ${ }^{73}$ Wallen gave his clients precisely the form of church they required, ones in which all could hear and see the preacher. And it should also not be overlooked that to build as the Ecclesiologists wanted to build was usually very expensive, while Wallen's clients were, in almost every instance, pitifully impecunious. The edition of the Leeds Intelligencer that reported the opening of Milnsbridge church in 1845 also noted the completion of J. M. Derrick's St Saviour's, Leeds, an early model of the new Ecclesiological thinking. ${ }^{74}$ The latter had cost around $\mathcal{E} 17,000$ and even then, was without its intended tower; it held just 600 


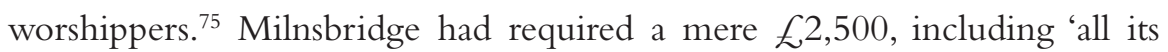
fittings and hot water heating system' and provided places for $945 .{ }^{76}$ The 'neat and picturesque' Gothic chapel at Aspley cost only $\mathcal{E}^{500 .{ }^{77}}$

\section{Wallen's secular buildings}

Archives concerning the building of secular structures rarely survive on the scale of that devoted to Anglican projects, and what was recorded of Wallen's secular work is, almost certainly, only a fraction of what he actually did. Nevertheless, what is known reveals engagement with a range of building types and demonstrates Wallen's competence with a number of styles, but especially with the Italian Renaissance Revival which placed him absolutely at the forefront of fashion in the 1840s.

The first notice of a commission unconnected with the Church of England came in 1840: the interior design for the 1840 Huddersfield Exhibition, held at the Philosophical Society's premises: 'The rooms will be beautifully decorated in the Saracenic order under the direction of Mr Wallen'; ${ }^{78}$ sadly, no images survive. It was a modest project, but one useful in promoting Wallen among the town's elites. The patrons included Earl Fitzwilliam and the Earl of Zetland, both Trustees of the Ramsden Estate, and the list was headed by the Archbishop of York and the Bishop of Ripon, underlining Anglican support, although David Griffiths stresses the exhibition's non-sectarian philosophy. The organising committee's chairman was Joseph Brook, partner in the Meltham Mills company whose family we will encounter below.

Also in 1840, Wallen surveyed the roofs of Fixby Hall for Thomas Thornhill. ${ }^{79}$ It was another minor job, but it was through these mundane appointments that useful contacts might be made. In this instance, just two years later, in 1842, Thornhill, in his capacity as lord of the manor of Calverley, donated the site for the new church of St John, Farsley, near Leeds, which Wallen designed. Did Thornhill promote Wallen for the job; it seems unlikely to have been merely coincidence? And in 1844, Wallen was appointed to survey Calverley's parish church.

More significant architecturally, in 1842 or 1843, Wallen was engaged to build Eshold House at Woodlesford, near Leeds, for Henry Bentley, owner of the nearby Eshold Brewery. ${ }^{80}$ Completed in 1844, it is a substantial mansion with a huge service wing. The stylistic and planning similarities between Esholt and Meltham Hall, Huddersfield, erected c.1841-3 for William Leigh Brook who inherited Meltham Mills on the death of his father in 1845, make it highly likely that Wallen designed both. Brook had a life membership of the Yorkshire Architectural Society which would have provided a convenient link to Wallen and, like the rest of his family, Brook was a committed 


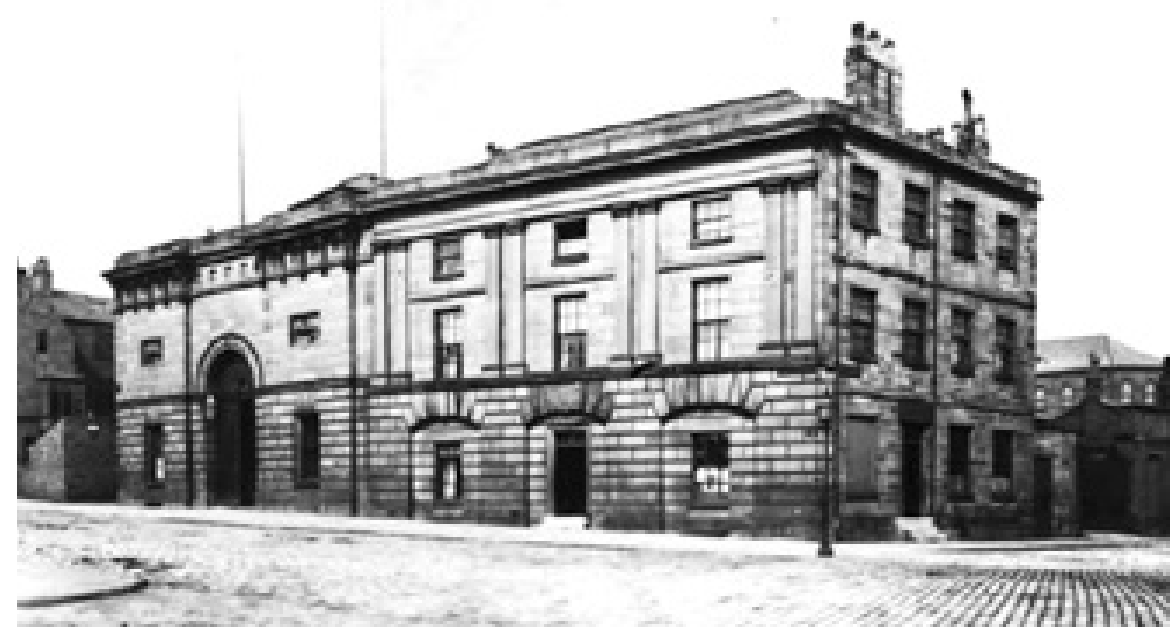

37. Riding School, 1846-7 (subsequently altered, left) and Zetland Hotel, 1846-7 (right), Ramsden Street (now Queensgate), Huddersfield, both by William Wallen.

Kirklees Image Archive

Anglican although his father, James (d.1845) employed Pritchett to design his ecclesiastical projects, beginning with the tower for St Bartholomew, Meltham, in 1835. Other known projects by Wallen for major families in the Huddersfield area included the new estate office at Longley Hall for the Ramsdens in 1848 [see Illustration 9, p. 15]. ${ }^{81}$

In 1846, Wallen was responsible for the Riding School and Druid's Hotel - later the Zetland Hotel - in Ramsden Street. Although adjacent, it seems they were discrete projects. ${ }^{82}$ The hotel is an elegant design which looks back to an earlier Palladian tradition, while the Riding School reflects cutting edge 1840s Classicism: Italian Renaissance Revival. Grecian - as exemplified by Oates' Infirmary of the early 1830 s - was increasingly seen as passé, replaced by the new Renaissance style in fashionable circles. The deeply overhanging cornice supported by substantial brackets are clear references to the style, popularised by the publication in Paris of Paul Letrouilly's Édifices de Rome Moderne, (3 volumes, 1840-57). It quickly became the standard textbook of examples and perhaps Wallen owned a copy.

\section{St George's Square}

The Riding School was a modest-sized building, but it was only a small step, stylistically, from this to the design for the George Hotel (1849-51), 
the crowning achievement of Wallen's years in Huddersfield [see Illustration 23, p. 59]. The scheme seems to have originated in September 1845 when Alexander Hathorn, the Ramsdens' local agent, wrote to George Loch, the estate steward, setting out what he saw as the opportunities the arrival of the railway offered. He was keen that the Ramsdens, not the railway shareholders, should be the principal beneficiaries. Fitzwilliam was enthused, securing the station commission for Pritchett and laying the foundation stone himself in $1846 .{ }^{83}$ The outcome of Hathorn's initiative was a dignified new street leading from the town and an impressive new 'square' in front of the station surrounded by an outstanding set of buildings, the work of a number of mainly local architects. In terms of both the acreage covered and the architectural magnificence of the new buildings, it was a scheme almost without parallels among the northern industrial towns. Only the development of Newcastle upon Tyne in the second quarter of the century could rival it. William White, publishing in 1853, concluded 'St George's Square and the new streets opening into it, are the handsomest parts of Huddersfield, being spacious, and lined with elegant stone buildings. ${ }^{84}$ The Huddersfield Chronicle enthused, not unreasonably, 'from the front of our noble station ... Huddersfield is one of the most splendid towns in the kingdom ${ }^{85}$ and it praised Wallen's new hotel.

This was, indeed, a remarkable piece of town planning in terms of scale and ambition. Absolutely central to the successful completion of the project was that the land was in single ownership: the Ramsdens. In, for instance, Bolton, Bradford, Leeds or Manchester, land ownership was so fragmented that development on anything other than a modest scale was impossible. But in Huddersfield, with a combination of long-established ownership by the Ramsdens, and a series of astute recent purchases masterminded by Loch and Hathorn, it was indeed possible. In terms of scale, it was a town centre development almost without precedent in England, but what was equally important was the Ramsden determination to have only buildings of the highest order. It was a commendable vision, overseen from 1851 by the eminent London architect, William Tite. ${ }^{86}$

Wallen's design for the George was accepted in January 1849; despite the admiration generated by Pritchett's station, the latter had, by then, annoyed Isabella Ramsden, which perhaps precluded him from being invited to design the hotel. Significantly, it was 'the only building in the square for which the Trustees had to pay', suggesting Wallen was held in high regard. Indeed, Loch judged it 'the most substantial and best constructed edifice I know anywhere' - praise indeed. It cost $\mathcal{f}_{10,470-14-2 .{ }^{87}}$

The station is, indeed, magnificent: majestic in scale and perfectly sited. But it is also an old-fashioned design: Palladianism tricked out with a few Grecian details. ${ }^{88}$ The George Hotel - 'one of the largest and handsomest 
hotels in England', according to White ${ }^{89}$ - is, on the other hand, ultrafashionable Italian Renaissance, a stunning development from Wallen's earlier, more modest essay in the style, the Riding School in Ramsden Street. It is by comparing the station and the hotel that the approximately two decades that separated the architectural education of Pritchett and Wallen becomes noticeable. The George really was cutting edge Parisian fashion brought to Huddersfield via Letrouilly's books. The style is typified by quoins marking the corners of walls, deeply overhanging cornices supported by brackets, an absence of an architrave - usually an essential component in a Classical entablature - and a rusticated ground floor. All these details can be found in Letrouilly's illustrations. It was a style to be found in London, but was one that largely escaped West Yorkshire until much later. The refinement and subtleties of the style are clear if one compares the George with slightly later buildings in the square. Britannia Building (by William Cocking, c.1858), reflects Tite's fondness for a somewhat ostentatious species of Classicism with exuberant sculptural decoration and a heavy parapet; Pritchett's Lion Building (1852-4) remained a clumsy design, despite Tite's best endeavours to correct it. ${ }^{90}$

Wallen's final landmark contribution to central Huddersfield was six shops and attached warehouses on the corner of Westgate and the new John William Street (c.1852-3). ${ }^{91}$ It is another sophisticated, thoughtfully proportioned Classical composition, but deliberately more understated than the George as befitted the buildings' function and street location. The block was important in establishing what soon became the standard street architecture of midcentury Huddersfield, the 'spacious' thoroughfares lined with 'elegant stone buildings', described by White. ${ }^{92}$

\section{Castle Hill}

The next group of projects had rather more chequered gestations.John Rumsby tells us that 'a tavern to cater for pleasure-seekers was first built on [Castle Hill, Almondbury] in about $1810-11,{ }^{93}$ and through the nineteenth century the hill was a popular location for walkers, political rallies and for church and chapel outings. In 1848 Wallen wrote to the Ramsden Estate to request 'a site for a prospect tower on Castle Hill, ${ }^{94}$ a project which he stated he had had in mind some years. He wrote again early the following year seeking the Estate's support: if approved, it 'may be finished this season', ${ }^{95}$ Wallen claimed confidently. It seems there was much local support, 'a model was made, a committee formed and financed organised. ${ }^{96}$ The building was to have included 'a restaurant, museum and observation room', ${ }^{97}$ and 'accommodation for private picnic parties [likely to be popular as] Huddersfield was without any place of attraction for visitors.'The tower was to be 'about 26 feet square 
... and the total height [was to be] 95 feet so that the summit ... would be nearly 1,000 above the level of the sea' with extensive views. The cost was estimated at $\mathcal{E} 1,200 \cdot{ }^{98}$ However, in 1849 Isabella Ramsden objected strongly, claiming that her son's 'antiquarian taste is quite shocked at the idea of the old fort ... on Castle Hill being disturbed for a new erection of any sort or kind. ${ }^{99}$ Nevertheless, in 1851, at the 'Huddersfield Brewster Sessions ... it was stated that the tower, talked of some time ago ... was now likely to be proceeded with and that Mr Wallen ... had his plans ready for that purpose.'100 And in that year the Castle Hill Hotel opened, but, confusingly, this seems to have been an entirely separate project.

The narrative is further complicated by simultaneous discussions concerning a monument to Robert Peel. A letter signed 'Alpha' - could this have been Wallen using a pseudonym? - appeared in the Huddersfield Chronicle on 3 August 1850.

A very pretty plan and model for a tower on Castle-hill ... were prepared by our talented architect, W. Wallen, with whom originated the idea of marking the spot where stood the old Roman fortress ... also to serve as an observatory for astronomical and other purposes for the whole county, which design would have been carried out but for some slight difference in respect of the ground. Now, it strikes me the same tower, if erected, might serve a twofold purpose, viz that for which it was originally intended, and a lofty base for a colossal figure of that statesmen.

It concluded, 'Should this meet the views of the committee formed for carrying out the proposed monument, it might also serve as an inducement to the trustees of the Ramsden Estate, to grant the necessary land for the purpose.' Clearly the Ramsdens were still not enthusiastic and nothing came of this proposal or the tower, although Wallen was to be involved in other schemes to honour Peel.

Was there any relationship between the Castle Hill Hotel and the Castle Hill Tower? Although sharing a similar location, their functions and intended clienteles were significantly different. It seems it was Ramsden opposition, as noted in Wallen's 1850 letter quoted above, that killed the tower project. But if the Ramsdens objected to a tower, why did they not also object to the hotel? Probably the hotel was a rebuilding of the existing inn in a style which reflected the vernacular traditions of the area and could almost have been mistaken for a seventeenth century yeoman's house. 


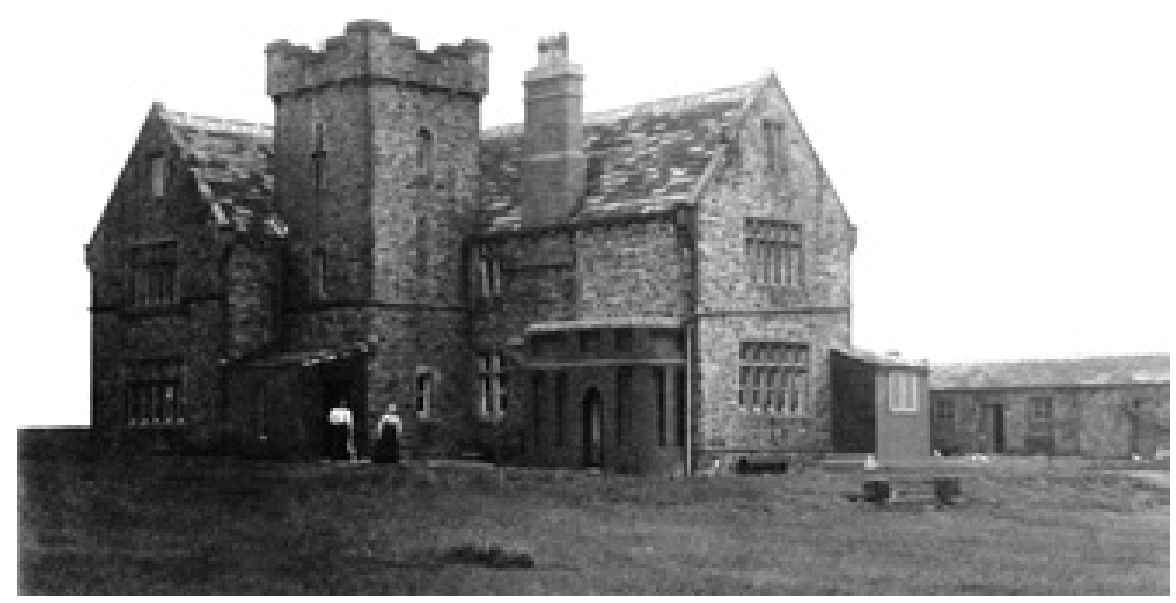

38. Castle Hill hotel (1851), usually ascribed to William Wallen. Huddersfield Local Studies Library

\section{The Peel Monument}

Following Robert Peel's death on 2 July 1850, the good citizens of Huddersfield lost no time in considering the erection of a fitting monument. A committee of forty-four was formed to consider proposals, ${ }^{101}$ and early in 1851 a competition was organised which solicited as number of designs from architects. The Chronicle devoted much space to the project, beginning a long article with a discussion of possible sites, concluding the only sensible one was in the new square in front of the station, one the Ramsdens were reluctant to provide. It then proceeded to assess in detail eight anonymously submitted designs, concluding that design III 'was by far the most appropriate among the sketches we have seen. ${ }^{102}$ Later it transpired Wallen was the author of design III, which was a 57-feet high Classical column surmounted by 'a Funeral Urn' ${ }^{103}$ The committee was unable to agree on either a design or a location, and nothing further was done. ${ }^{104}$ However, the project was revived in 1868 and eventually, in 1873, a statue of Peel was erected in front of the station [see Illustration 22, p. 59]. ${ }^{105}$

\section{Wallen's status in Huddersfield and final legacy}

We have only scant details of Wallen's private life during his Huddersfield years. He appears to have lived the sort of life that could be expected of 
a successful professional gentleman. Initially he resided in Buxton Road/ Chapel Hill ${ }^{106}$ but by 1842 he had moved to 41, West Parade. ${ }^{107}$ In 1850 he was living a little further out from the centre in fashionable New North Road, at no 2. ${ }^{108}$ His activities with the Yorkshire Architectural Society and lectures for the Geological and Polytechnic Society of the West Riding were regularly reported in the region's newspapers and must have brought him some academic eminence. Similarly, his earlier publications continued to be advertised, although his planned Guide to Castle Hill, Almondbury, with Historical, Typographical and Antiquarian Notices, advertised in 1852, remained unfinished. ${ }^{109}$ And within his profession, he was sufficiently well-regarded to have been appointed as an arbitrator in the Leeds architect John Clark's dispute concerning the Leeds Industrial School competition in 1846. ${ }^{110}$ Finally, in the early 1850s, he was one of around 50 'Directors' of the Agbrigg Savings Bank. ${ }^{111}$ It all suggests middle-class respectability.

It had long been believed that Wallen died in 1853 or 1854, but Isaac Hordern, the Ramsden Estate's cashier, recorded that Wallen did not see the completion of the chapel at Aspley in 1854, 'as he had to go to a private doctor's home. ${ }^{112}$ It is now clear that he lived until 1888 and spent the last thirty-five years of his life as a patient at Bootham Park Hospital, York, the county's lunatic asylum. He was admitted on 8 September 1854 and died there on 1 May $1888 .{ }^{113}$

\section{Wallen's legacy}

After about 1850 Huddersfield's attitudes to where architects resided changed. No longer was employing a man with a local address the ultimate stamp of prestige; now a London address was pre-eminent. The town's two most significant churches from this decade - St John, Bay Hall (1851-3) [see Illustration 29, p. 136] and St Thomas, Manchester Road (1857-9) - were by eminent London designers; and while most of the impressive 1850s buildings surrounding St George's Square were by local men - Cocking, Pritchett and Wallen - in 1851 it was a London architect, William Tite, who was appointed to inspect designs and maintain standards. ${ }^{114}$

However, it is clear that Wallen had enjoyed a high reputation in Huddersfield. Aside from his architectural contribution to the town and beyond, he was a Fellow of the Society of Antiquaries and had been a committee member of the Yorkshire Architectural Society. He had published a number of significant archaeological books and pamphlets, and enjoyed some eminence as a lecturer. In one of the last newspaper notices of him - the opening of the chapel at Aspley in 1854 - the Chronicle referred to him as, 'the architect who has so well adorned the locality'. ${ }^{115}$ 


\section{Wallen and the Ramsdens}

What was Wallen's relationship with the Ramsdens and their agents? Pritchett was initially the family's favoured architect, a position seriously dented by the 1842 partial collapse, during reconstruction, of St Edward, Brotherton. In 1844, having read in the Leeds Mercury that Fitzwilliam had recently visited Huddersfield accompanied by Pritchett, Isabella Ramsden repeated a warning she had first issued to George Loch the preceding August:

Now, he [Pritchett] must not be employed in his profession, on any work, for which the Ramsden family are expected to pay. - He has given us a lesson we shall not forget. - He must not be employed by the Trustees. - ... we [the Ramsdens] are resolved that we will not have any thing now to do with him. ${ }^{116}$

However, it seems Fitzwilliam was unmoved and Pritchett's most memorable addition to Huddersfield and one that was the result of Ramsden patronage - the railway station - was yet to be started.

Nevertheless, this spat can only have aided Wallen's position. Yet he too managed to fall out with Mrs Ramsden in 1849 over the Castle Hill Tower. More positively, in 1851 he prepared plans for 'covering the Market Place ... The idea seems to have originated with ... Isabella Ramsden who felt that the ladies of the area, who bought [items there] deserved some covered accommodation.' However, nothing came of the proposal. ${ }^{117}$ In contrast, his 1848 commission to design the estate office at Longley Hall, the family's Huddersfield base, was successfully completed, ${ }^{118}$ and probably in the same year Wallen began work on the new George Hotel. This was to be the Ramsdens' principal contribution to the 'New Town' of Huddersfield that came with the railway ${ }^{119}$ and the choice of architect is unlikely to have been a matter of indifference. It was both Wallen's most significant project for the Ramsden Estate and his most memorable addition to Huddersfield.

More generally, the Ramsdens - or more usually their agent - seeking to maintain high standards of design, inspected all proposals for new buildings on land that formed part of the Estate and would thus have been familiar with other Wallen commissions. This was particularly the case from 1844 when George Loch was appointed Manager of the Estate - a responsibility he undertook much more diligently than his predecessor - and introduced strict supervision of new buildings. Thus in 1846 Wallen, seeking to have the Riding School 'covered before winter which is very desirable', complained of delays the inspection process generated. ${ }^{120}$

Any architect seeking success in the town after 1844 would have had to impress Loch; in this respect, Wallen probably had a distinct advantage. 
Loch, father and son, had extensive metropolitan connections and would have known, or known of, Wallen's father, John, the 'principal quantity surveyor [in the 1830s] in the City'. ${ }^{121}$ Estate managers might have had only limited interest in architectural niceties, but quantity surveying and the erection of functional buildings to increase mercantile efficiency - where John Wallen excelled - certainly came within their domain. It is thus very unlikely that the Lochs and the Wallens were unknown to each other. They would, in modern parlance, have 'spoken the same language'. However, when it came to ecclesiastical projects, in the 'new' world of Ecclesiological imperatives, any closeness between the families would have counted for little.

A Ramsden project that gives useful insights into both how the family saw itself as well as its relationship with Wallen and Pritchett is the new church of St John, Bay Hall, begun in the late1840s and closely associated with Isabella Ramsden. Following the debacle at Brotherton, employing Pritchett is unlikely to have been countenanced, but did they consider Wallen? He had, by this time, a succession of well-regarded, structurally sound churches to his credit. The answer is deeply embedded in the revolution of attitudes to the design of churches and to the liturgy that would take place within them, brought about by the Ecclesiologists whose influence from the early1840s was enormous. It was a movement closely associated with elite groups at Cambridge University and, to a lesser extent, at Oxford. Concurrently, financing church building moved from being something the wealthy middleand upper-classes often rather resented - as noted in Sir John Ramsden's grudging contribution to the rebuilding of Huddersfield parish church in 1834-6 - to something to be done with generosity and enthusiasm. The Ecclesiologists made 'medieval authenticity' in the style, layout and detail of new churches beyond question, while social reformers made the support of church building a Christian duty: 'Nothing can be so sacred, so public, so permanent, so really benevolent, so truly gracious an offering, as a building devoted to the Living God. ${ }^{122}$ The cynic might conclude that the support of church building became something of a fashionable past-time, although one undertaken with earnest.

Wallen made a name for himself building cheap, plain churches for 'Low' Anglican congregations of a type loathed by the Ecclesiologists they are not churches at all, merely 'sermon houses', they thundered [see Illustration 36, p. 157]. ${ }^{123}$ These might have served Huddersfield's industrial worshippers perfectly well but, thanks to Ecclesiology, they would struggle to be accepted by polite society. Pritchett's completed churches were at least as unacceptable in the context of the new imperatives. His ecclesiastical solecisms included St Peter, Bafferton, North Yorkshire (1826-31) where he rebuilt the nave of the medieval church to create a 'preaching box' orientated 
north-south, sandwiched between the original tower and chancel, and, worse still, in 1816 he had built the new St Nicholas, Norton, East Yorkshire - in Fitzwilliam territory - in the Grecian style. Using 'pagan' idioms was, for the Ecclesiologists, the ultimate sin. If the Ramsdens were to capitalise on their generosity at St John's they needed to impress their equals at least as much as their tenants. Thus, while they were content to let Pritchett author the new railway station and Wallen design the estate office at Longley Hall or the George Hotel, neither could, in the new climate, be entrusted with a 'Ramsden' church; this was a job for a big-named metropolitan architect, one who carried the Ecclesiologists' stamp of approval. The initial choice was London-based Edward Blore who had recently completed Buckingham Palace and was currently engaged at Windsor Castle and Hampton Court; Loch would have known Blore through the latter's work on the Bridgewater estate at Worsley, Lancashire, where he was also the agent. It is a mark of Ecclesiological dogma that even an architect of Blore's eminence was pilloried for his churches: his Christ Church, Hoxton, London, was deemed a 'truly contemptible building' by an architect 'entirely unacquainted with the true spirit of Pointed architecture.' ${ }^{124}$ His design was also too expensive and so the commission went to William Butterfield, widely seen as the Ecclesiologists' favoured son. ${ }^{125}$ By 1851 , when construction started, Butterfield was also busy with his designs for Adelaide Cathedral.

Thanks to the Ramsdens' careful oversight of Huddersfield, the midnineteenth century town was indeed 'one of the most handsome towns in the kingdom', and local architects played the major part in this. However, by the mid-1840s, church-building had become so over-laid with the demands of the High Church agenda that its funding needed to be approached with circumspection. If high profile donors like the Ramsdens were to capitalise on their largesse, they needed to build the 'right' sort of church.

\section{Endnotes}

1 Baines (1822), pp. 134-5; White (1853), p. 443.

2 Baines (1822), p 188; White (1853), p. 561.

3 Baines (1809), p. 44; Slade (1851), p. 467.

4 Baines (1822), p. 149; White (1853), pp. 142-3.

5 Although Pigot (1834), p. 261, does include Joseph Kaye in his Huddersfield Architects list.

6 Quoted in Wyles (1992), p. 303.

7 Attributed on the basis of its stylistic similarity to Pritchett's York County Savings Bank, York (1829-30).

8 Whitaker (1816), p. 65.

9 For a useful overview of Huddersfield in 1840, see Griffiths (2011a), pp. 176-8. 
10 An 1848 commentator, quoted in Wyles (1992), p. 303.

11 White (1853), p. 596.

12 For Kaye's career, see Law (1989).

13 Among the books, Nicholson (1798) ran to many editions between 1798 and 1835. Examples of tradesmen turned 'architects' include, in Leeds, Lawrence Ingham and Benjamin Jackson, and in Wakefield, John Robson.

14 Pigot (1834), p. 261.

15 Soane (1788), p. 7.

16 For Pritchett, see ODNB (2004), 'Pritchett, James Pigott (1789-1868)' and Colvin (2008), pp. 834-7.

17 Jenkins (2017), p. 247.

18 Sheffield Independent and Yorkshire and Derbyshire Independent, 3 July 1830.

19 Wyles (1992), p. 308.

20 For details of his pupils, see Webster (2010), p. 10. This also provides more thorough coverage of Wallen's pre-Huddersfield activities.

21 Robson (1831), p. 173; Shepherd (1957), p. 167.

22 For a fuller account of Wallen's antiquarian pursuits, see Webster (2010).

23 Graves (1907), p. 291.

24 The committee meeting of 7 May 1835 received his application: Society of Antiquaries, Minute Book 36, pp. 488-9, 510.

25 Wallen (1836).

26 Architectural Magazine, 3, 1836, p. 227.

27 Civil Engineer and Architect's Journal, I, 1838, pp. 156-8.

28 Lambeth Palace Library, Incorporated Church Building Society archive, ICBS file 01422 .

29 I am grateful to Christopher Marsden for information about Ward's places of residence.

30 ICBS file 01422, Lewis Jones to ICBS, 2 January 1838, asking the ICBS to tell Mr Chantrell what further changes it wanted.

31 ICBS file 01422, Jones to ICBS, 3 March 1838.

32 ICBS file 01422, Chantrell to Jones, 21 January 1839: 'on 18 March [1838] when you came over to Leeds with the Farnley Tyas Estimates [Chantrell was in the process of building this church in the Almondbury parish] and proposed to me to execute another person's design'.

33 ICBS file 01422, Wallen to ICBS, 17 March 1838.

34 LI, 2 June 1838; 1 August 1840.

35 WYAS, Wakefield, WDP12/178, Almondbury Parish Records, Minute Book, 1825-1885.

36 Foundation stone laying, LI, 30 March 1839.

37 Brook (1968), p. 199.

$38 L M, 2$ Feb 1839. Wallen was a shareholder, LM, 26 May 1838.

39 LI, 2 December 1838.

40 The precise date of opening seems not to have been recorded.

41 ICBS file 02999; WYAS, Leeds, BDP26, Farsley Parish Records.

42 Bradford Observer, 6 July 1843.

43 LI, 27 January 1844; WYAS, Bradford, BDP78, Oakworth Parish Records.

44 ICBS, file 03891.

45 HC, 11 March 1854 reported the opening stating the new chapel 'was not far from the old Lecture-room' which, presumably, was a temporary chapel. Clearly there were two 
discrete buildings but the new chapel was often referred to as 'the Lecture Room', e.g. HC, 25 January 1868.

46 ICBS, file 02498. The application was unsuccessful.

47 Tenders requested, $L I, 14$ October 1843.

48 HC, 26 June 1852.

49 Weatherhead (1913), p. 40. Weatherhead records that Wallen asked for only 'a donation of $\mathcal{E}_{10-0-0}$ ' for his professional services.

50 WYAS, Wakefield, WDP 24, Holmbridge Parish Records, nos 87 and 98.

51 Tenders requested, LI, 21 Sept 1844.

52 Tenders requested, LI, 28 December 1844.

53 WYAS, Wakefield, WDP 143, Marsden Parish Records, no 38.

54 Tenders requested, $L I, 1$ August 1846

55 Harman and Pevsner (2017), p. 353.

56 For the Cambridge Camden Society, see 'Introduction' in Webster (2003).

57 This appears in a hand-written statement in the YAS's first Minute Book (1842-6), p. 2:York Minster Library, YAS, 2001/178, box 10 b.

58 The paper delivered in York is variously referred to as being on 'The Geometrical Principles of Gothic Architecture' and on 'The Geometric Principles of Gothic Tracery', whereas the Halifax one was on '... Gothic Architecture'. York Minster Library, YAS Minute Book, 1842-6.

59 Information about the society's meeting is to be found in Minute Book 1. Minute Book 2, covering $1847-50$ is missing and Wallen is not mentioned as a committee member in the one covering 1851-7.

60 The society's membership records are patchy but from 1850 were published in Associated Architectural Society Papers and Reports. The first volume, for 1850, shows Wallen as a member.

61 Wallen (1842).

62 See Scholfield (1958), ch. 5; Morgan (1961), p. 17. For more on Wallen's contribution to the subject see Webster (2010), pp. 20-1.

63 Wallen (1842), pp. 5-7.

64 For instance, see the c.1842 plan for Farsley in WYAS, Leeds, BDP 26/31 and the plan of the finished building in ICBS, file 02999.

65 Ahier (1949), p. 229. The pre-Ecclesiological interior arrangement of Christ Church, Linthwaite (built 1827-8) still remained unmodernised at the end of the century. In a national context, it was a very rare survival.

66 In addition to the publications discussed already, Wallen subscribed to most of the parts of Poole and Hugall (1842-4), the best survey then of the county's medieval parish churches.

67 Wallen (1842), p. 7.

68 Wallen (1842), p. 20.

69 For more discussion of Wallen's views about church design, see Webster (2010), p. 23.

70 Wallen (1842), p. 4.

71 See Crook (2003), pp. 84-120.

$72 L I, 5$ October 1840.

$73 L I, 11$ October 1845. For more discussion of the reception of Wallen's churches, see Webster (2010), pp. 24-5.

74 LI, 11 October 1845.

75 I am grateful to Christopher Tyne for this information. 
LI, 11 October 1845, although the [London] Morning Post, 18 November 1845, gives the number of seats as 602 .

HC, 11 March 1854.

LM, 9 May 1840. I am grateful to Christopher Marsden for this reference. For a thorough discussion of the exhibition, see Griffiths (2011a), pp. 175-98.

DD/T/S/a/41, Thornhill Papers, Report on the Condition of Roofs at Fixby Hall, 26 September 1840 .

LI, 27 January 1844.

Law (1986) p. 59. See chapter 1, pp.14-18

Tenders requested LM, 27 June 1846 (Riding School), 10 October 1846 (Druid Hotel).

Wyles (1992), p. 308.

White (1853), p. 596.

HC, 11 March 1854.

See chapter 2, pp. 61-2.

'Abstract of New George Hotel Building Account', quoted in Whomsley (1974), note 139. I am grateful to Brian Haigh for alerting me to this item.

Jenkins (2017), p. 248, even suggests Pritchett 'echoed' Fitzwilliam's mansion, Wentworth Woodhouse, built a century earlier.

White (1853), p. 596.

Wyles (1992), p. 312.

Tenders were advertised in HC, 26 June 1852.

White (1853), p. 596.

Rumsby (1992), p. 10.

DD/RE/C/50, Wallen to Loch, 10 July 1848, quoted in Law (1986), p. 58.

DD/RE/C/56, Wallen to Loch, 11 January 1849.

Law (1986), p. 58; LM, 3 March 1849.

Rumsby (1992), p. 11.

HDC, 3 July 1899. This 'Correspondence' from Isaac Hordern included a detailed account of Wallen's proposal and the names of those on the Management Committee: Hordern, 'Notes', 1851, p. 24; 1898, p. 197.

WYASK, DD/RE/c/59, Isabella Ramsden to Loch, 15 April 1849.

LM, 23 August 1851.

Minter (1996), vol. 2, p. 3.

HC, 15 March 1851.

The designs received much coverage in the Chronicle thanks to letters from 'Josephus J. Roebuck, Civil Engineer' criticising Wallen's designs and responses from Wallen. HC, 15 March 1851, 29 March 1851, 5 April 1851, 12 April 1851, 5 June 1852. Wallen had also submitted design $\mathrm{V}$.

See chapter 2, pp. 73-4.

Minter (1996), vol. 1, p. 3.

Correspondence in ICBS, file 01422.

Williams (1845), p. 69.

HC, 5 June 1852. HC, 26 June 1852, confusingly still gave his address as West Parade. HC, 9 October 1852.

LM, 4 April 1846. I am grateful to Christopher Marsden for this reference. See also C. Webster, 'John Clark (1798-1857)' in Webster (2011), pp. 132-3.

HC, 25 January 1851, 5 February 1853.

Hordern, 'Notes', 1853, p. 35. 
113 University of York, Borthwick Institute, NHS/BOO/6/2/3/2, Registry of Admissions Book, 6 Nov 1850-10 Sept 1855. Many of the details that follow are based on information generously supplied by Gary Jones of Brisbane, Australia, a distant relative of Edward Jones, one of John Wallen's pupils. I am grateful to him for sharing this information.

114 Wyles (1992), pp. 308, 312.

115 HC, 11 March 1854.

116 WYASK, DD/RA/C/4/1, Isabella Ramsden to Fitzwilliam, 9 November 1844; see also DD/RE/C/3/26, Isabella Ramsden to Loch, 20 August 1844.

117 WYASK, DD/RE/C/90, Isabella Ramsden to Loch, 2 November 1851, quoted in Law (1986), p. 59; see chapter 2, p. 65.

118 See chapter 1, pp. 14-15.

119 Marsden (2018), un-paginated.

120 WYASK, DD/RE/C/25, Wallen to Hathorn, 1 June 1846.

121 DNB (1890), vol. 28, p. 408.

122 British Critic and Quarterly Theological Review, 26, 1839, p. 461.

123 Neale and Webb (1843), p. xxiii.

124 Ecclesiologist, 3, 1843, p. 99; ODNB (2004), 'Blore, Edward (1787-1879)'.

125 Brooks (2000), pp. 121-49. For Butterfield, see ODNB (2004), 'Butterfield, William (1814-1900)'. 